\title{
Musculoskeletal System
}

National Cancer Institute

\section{Source}

National Cancer Institute. Musculoskeletal System. NCI Thesaurus. Code C12754.

The system of muscles, tendons, ligaments, bones, joints and associated tissues that move the body and maintain its form. 